\title{
ETNOMATEMATIKA DALAM RAGAM HIAS MELAYU
}

\author{
Astri Wahyuni, Surgawi Pertiwi \\ Program Studi Pendidikan Matematika FKIP Universitas Islam Riau \\ astriwahyuni280@gmail.com, surgawipertiwi@gmail.com
}

\begin{abstract}
Abstrak: Budaya merupakan aset yang paling berharga yang dimiliki oleh suatu bangsa. Sehingga perlu dikelola secara bersama-sama dengan satu pemikiran. Serta dapat memberikan hasil yang bagus secara positif. Baik secara fisik maupun non fisik. Pendidikan merupakan pewarisan budaya bagi generasi muda dan proses pengembangan budaya bangsa untuk meningkatkan kualitas kehidupan masyarakat dan bangsa di masa mendatang. Oleh karena itu, pendidikan dan budaya merupakan suatu satu kesatuan yang utuh yang tidak dapat dipisahkan. Etnomatematika merupakan salah satu bentuk strategi pembelajaran matematika yang mengaitkan kearifan budaya lokal dalam pembelajaran matematika. Melalui etnomatematika konsep-konsep matematika dapat dikembangkan dalam praktek-praktek budaya. Dengan demikian diharapkan peserta didik dapat mengetahui bagaimana budaya mereka terkait dengan metematika. Unsur budaya yang dapat dikembangkan dan digunakan dalam pembelajaran matematika adalah ragam hias melayu. Ragam hias melayu merupakan unsur budaya yang berasal dari Riau dan berkembang di lingkungan masyarakat Riau
\end{abstract}

Kata Kunci: Budaya, etnomatematika, ragam hias melayu

Matematika merupakan sabset dari kehidupan manusia. Salah satunya budaya manusia, Budaya Melayu adalah kebudayaan masyarakat melayu yang tidak dapat di rubah dan selalu di lestarikan oleh masyarakat Melayu Terutama masyarakat Melayu di Pekanbaru. Dari pernyataan tersebut di ketahui bahwa dengan matematika Budaya melayu itu dapat di lestarikan salah satunya dengan mengaitkan Ragam Hias melayu dengan metateri Simetri Lipat dalam matematika.

\section{Pembahasan}

\section{Pengertian Etnomatematika}

Menurut Zulkifli dan Dardiri (2016) secara bahasa, etnomatematika terdiri tiga kata yaitu awalan "etno" yang artinya sesuatu yang sangat luas yang mengacu pada konteks sosial budaya, termasuk bahasa, jargon, kode perilaku, mitos, dan simbol. Yang kedua kata dasar "mathema" cenderung berarti menjelaskan, mengetahui, memahami, dan melakukan kegiatan seperti pengkodean, mengukur, mengklasifikasi, menyimpulkan, dan yang terakhir pemodelan. Akhiran "tik "berasal dari techne, dan bermakna sama seperti teknik.

Etnomatematika diperkenalkan oleh D'Ambrosio, seorang matematikawan Brasil pada tahun 1977. Definisi etnomatematika menurut D'Ambrosio adalah: The prefix ethno is today accepted as a very broad term that refers to the socialcultural context and therefore includes language, jargon, and codes of behavior, myths, and symbols. The derivation of mathema is difficult, but tends to mean to explain, to know, to understand, and to do activities such as ciphering, measuring, 
classifying, inferring, and modeling. The suffix tics is derived from techné, and has the same root as technique (Rosa \& Orey: 2011)

$\begin{array}{clc}\text { Menurut } & \text { Barton } & \text { (1996), } \\ \text { ethnomathematics } & \text { mencakup } & \text { ide-ide }\end{array}$
matematika, pemikiran dan praktik yang dikembangkan oleh semua budaya. Ethnomathematics juga dapat dianggap sebagai sebuah program yang bertujuan untuk mempelajari bagaimana siswa untuk memahami, memahami, mengartikulasikan, mengolah, dan akhirnya menggunakan ide-ide matematika, konsep, dan praktek-praktek yang dapat memecahkan masalah yang berkaitan dengan aktivitas sehari-hari mereka.

Secara bahasa Etnomatematika ialah "The mathematics which is practiced among identifiable cultural groups such as nationaltribe societies, labour groups, children of certain age brackets and professional classes" (D'Ambrosio, 1985) Artinya: "Matematika yang dipraktekkan di antara kelompok budaya diidentifikasi seperti masyarakat nasional suku, kelompok buruh, anak-anak dari kelompok usia tertentu dan kelas profesional" (D'Ambrosio, 1985) Istilah tersebut kemudian disempurnakan menjadi: "I have been using the word ethnomathematics as modes, styles, and techniques ( tics/) of explanation, of understanding, and of coping with the natural and cultural environment (mathema) in distinct cultural systems (ethno)" (D'Ambrosio, 1999, 146). Artinya: "Saya telah menggunakan kata Etnomatematika sebagai mode, gaya, dan teknik (tics) menjelaskan, memahami, dan menghadapi lingkungan alam dan budaya (mathema) dalam sistem budaya yang berbeda (ethnos)" (D'Ambrosio, 1999, 146).

Berdasarkan definisi tersebut, etnomatematika dapat diartikan sebagai matematika yang dipraktikkan oleh kelompok budaya, seperti masyarakat perkotaan dan pedesaan, kelompok buruh, anak-anak dari kelompok usia tertentu, masyarakat adat, dan lainnya. D'Ambrosio (1985) menyatakan bahwa tujuan dari adanya etnomatematika adalah untuk mengakui bahwa ada cara-cara berbeda dalam melakukan matematika dengan mempertimbangkan pengetahuan matematika akademik yang dikembangkan oleh berbagai sektor masyarakat serta dengan mempertimbangkan modus yang berbeda di mana budaya yang berbeda merundingkan praktek matematika mereka (cara mengelompokkan, berhitung, mengukur, merancang bangunan atau alat, bermain dan lainnya).

Dengan demikian, sebagai hasil dari sejarah budaya matematika dapat memiliki bentuk yang berbeda-beda dan berkembang sesuai dengan perkembangan masyarakat pemakainya. Etnomatematika menggunakan konsep matematika secara luas yang terkait dengan berbagai aktivitas matematika, meliputi aktivitas mengelompokkan, berhitung, mengukur, merancang bangunan atau alat, bermain, menentukan lokasi, dan lain sebagainya. Matematika memiliki sejarah panjang sebagai disiplin ilmu yang bebas budaya yang tersisih dari nilai-nilai sosial (D'ambrossio, 1999).Jadi dapat disimpulkan Etnomatematika ialah Suatu teknik atau gaya yang menjelaskan tentang Budaya.

\section{Budaya Bangsa}

Menurut Kamus Besar Bahasa Indonesia arti budaya adalah pikiran dan akal budi. Dengan demikian budaya dapat dikatakan sebagai sesuatu yang berkaitan dengan akal budi dan pikiran. Pendidikan dan budaya merupakan satu kesatuan yang utuh dan tidak dapat dipisahkan karena budaya 
merupakan pikiran dan pendidikan membutuhkan pikiran. Budaya adalah suatu keseluruhan kompleks yang meliputi pengetahuan, kepercayaan, kesenian, moral, keilmuan, hukum, adat istiadat, dan kemampuan yang lain serta kebiasaan yang didapat oleh manusia sebagai anggota masyarakat. Budaya merupakan hasil pemikiran manusia sebagai makhluk sosial.

$$
\text { Astri Wahyuni, dkk (2013) }
$$

menyatakan bahwa pendidikan dan budaya memiliki peran yang sangat penting dalam menumbuhkan dan mengembangakan nilai luhur bangsa kita, yang berdampak pada pembentukan karakter yang didasarkan pada nilai budaya yang luhur. Oleh karena itu, kita sebagai pendidik hendaknya mampu menanamkan nilai luhur budaya bangsa kepada setiap peserta didik melalui kegiatan belajar mengajar di kelas. Dalam hal ini guru harus mampu memimikirkan materi dan unsur budaya apa yang dapat dikemas sedemikian rupa sehingga menjadi pembelajaran matematika yang menarik dan dekat dengan kehidupan siswa. Budaya itu tumbuh dan berkembang di lingkungan hidup, sudah pasti dapat digunakan dalam pembelajaran di kelas. Sebagian guru bertanya-tanya bagaimana budaya dapat digunakan dalam merumuskan materi ajar yang digunakan dalam proses belajar. Di sisni, etnomatematikalah yang menjadi jembatan penghubung di antara keduanya. Salah satu contoh unsur budaya yang dapat digunakan adalah Ragam Hias Melayu. Bentuk atau motif dalam ragam hias melayu dapat dikaitkan dengan materi ajar simetri lipat bangun datar.

\section{Pelestarian Ragam Hias Melayu melalui Etnomatematika}

Taufik Ikram Jamil, dkk (2012:93) menyatakan bahwa bentuk seni rupa melayu riau adalah ukiran, kerajinan/tenun, dan gambar. Tetapi diantara bentuk-bentuk tersebut, ternyata bentuk ukiran dan tenun tergolong amat dominan dibandingkan bentuk gambar. Biasanya gambar dijadikan untuk membuat motif yang diinginkan dari ukiran maupun tenun. Selain itu, terdapat juga ragam hias melayu yang berkembang di tengah masyarakat.

Ragam Hias Melayu sering disebut Motif atau Ornamen Melayu . Dimana Ornamen melayu merupakan hasil karya manusia suku melayu. Menurut Tengku Luckman Sinar (Farizal Nasution, 2007: 230) ornamen melayu hanyalah sekelumit dari pada kesenian melayu tetapi secara umum di zaman dahulu banyak sekali dilakukan orang Melayu pada waktu senggang mereka, bahkan jauh sebelumnya, sejak masa kebudayaan Megalitik keahlian orang Melayu dalam pahat memahat patung, tidak di ragukan lagi seperti dapat kita saksikan pada sisa-sisa biara di Padang Lawas, Candi-candi di Muara Takus maupun peninggalan sisa patung dan biara di Palembang, Jambi dan kota Ciba (Labuhan Deli, Medan) ataupun kaligrafi pada batu nisan raja dan orang-orang yang terkemuka dan pada mesjid dan mimbarnya, pada rumah dan senjata-senjata.

Masyarakat melayu mengenal ornamen tertentu yang dapat diletakkan pada suatu benda, sehingga dengan meletakkan ornamen tersebut, benda itu kelihatan lebih indah dan lebih berwibawa. Ornamen yang biasanya dipakai ialah ornamen geometris. Sedikit sekali yang bermotifkan hewan dan tidak ada yang bermotif manusia.

Farizal Nasution (2007: 230) menyebutkan bahwa beberapa contoh Ragam Hias Melayu antara lain: Ragam Hias Bunga 
Matahari, Ragam Hias Tempung Pinang, Ragam Hias Genting, Tak Putus, Ragam Hias Roda Bunga, Ragam Hias Lilit kangkung dan Ragam Hias Pucuk Rebung.

1. Bentuk Ragam Hias Bunga Matahari berbentuk setangkai bunga matahari yang dikelilingi secara simetris dengan saluran daun-daun.Di kanan kiranya diberi hiasan bunga lengkap dengan vasenya, serta bingkai lengkung Gothik dan dibatasi dengan empat persegi panjang. Pada bagian atas terdapat sederetan susunan bunga matahari dan tidak memakai daun. Ragam hias bunga matahari ini berbentuk empat persegi panjang, yang berisikan ukiran yang bermotif bunga matahari, sedang pada bagian atasnya terdapat hiasan geometris.

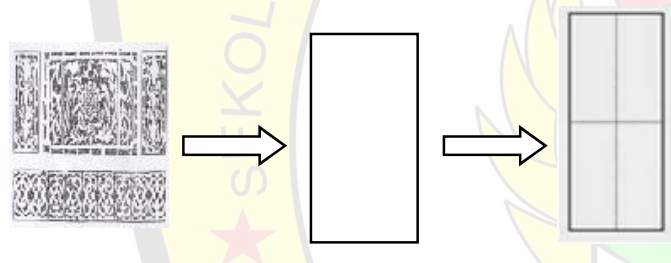

Simetri Lipat Persegi Panjang

2. Ragam Hias Tapuk Pinang merupakan susunan tampuk pinang. Satu dengan lainnya saling berkaitan / dan berhubungan sehingga mengingatkan pada bentuk tegel. Ragam hias ini dapat diperpanjang atau diperpendek sesuai dengan tempat yang telah disediakan nantinya.

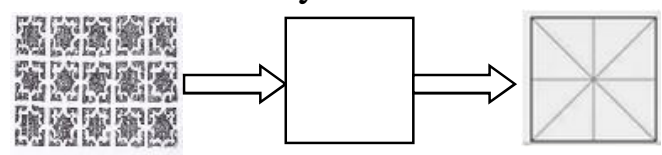

\section{Simetri Lipat Persegi}

3. Ragam Hias Genting Tak Putus merupakan lengkungan yang berlilitlilit ke kanan dan kekiri, saling kait mengait dengan variasi daun yang selalu disusuaikan dengan tempatnya berada. Ada kalanya yang digabung dengan bentuk-bentuk fauna seperti burung ataupun ikan dan lain-lain. Makna dari ragam hias ini bahwa sesusah-susahnya manusia dalam hidup ini tetapi tidak sampai habis sama sekali. Ragam Hias ini berfungsi sebagai ventilasi pada bagian dalam

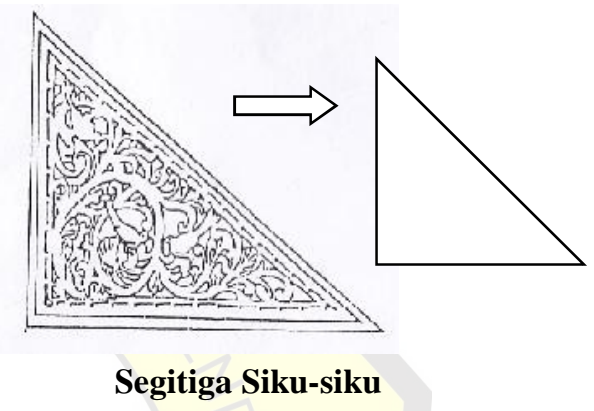

4. Ragam Hias Roda bunga (Groda Bunga)

Ragam Hias ini berbentuk setengah lingkaran, yang mengingatkan pada setengah roda dengan hiasan jarijarinya dibuat dari tangkupan bunga. Pada sudut atas di kanan kirinya diisi dengan hiasan, bentuk mahkota dari sulur-sulur daun dan bunga. Kesemuanya dibatasi dengan bentuk empat persegi yang merupakan bingkai. Raram hias ini melambangkan kemakmuran

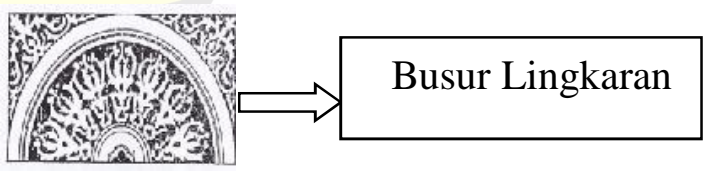

5. Ragam Hias Lilit Kangkung

Ragam hias ini merupakan hiasan, yang memanjang mengikuti garis-garis lurus. Melilit ke kanan atau ke kiri dengan berbagai variasi sehingga mengesankan menunjang bagi arah yang tegak dan melebar bagi arah 
horizontal. Ragam Hias ini diletakkan di tiang atau les dinding rumah.

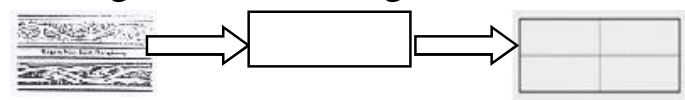

Simetri Lipat Persegi Panjang

6. Ragam Hias Naga Berjuang

Ornamen Naga Berjuang ini terdapat pada lobang hawa di rumah salah seorang penduduk di desa Lima Laras Kecamatan Tanjung Tiram. Naga Berjuang melambangkan kemampuan. Jadi ornament ini biasanya dipakai oleh penduduk yang serba kecukupan di dalam kehidupan ekonominya. Bentuk ragam hias naga berjuang adalah merupakan dua ekor naga yang saling berhadapan dalam ruangan setengah lingkaran dari bahagian empat pesegi panjang yang dikomposisikan dengan baik sekali.

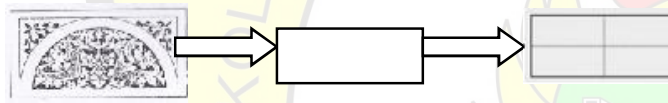

\section{Simetri Lipat Persegi Panjang}

7. Ragam Hias Jala-jala

Ragam hias ini berbentuk belah ketupat, karena hasil penyusunan ketupat yang sejajar dan saling berlawanan arah. Ragam hias jala-jala

hanya berwarna kecoklat-coklatan atau warna putih kapur saja. Ragam hias ini sangat sederhana, namun banyak dipakai. Ragam hias ini tidak memiliki arti apa-apa, hanya berfungsi sebagai ventilasi dan keindahan saja.

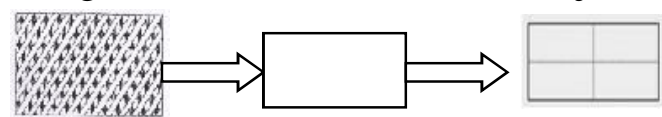

Simetri Lipat Persegi Panjang

8. Ragam hias kuda kencana

Suatu ornament tumbuhtumbuhan yang terdapat pada sebuah segitiga sama kaki. Terletak pada
Singab bahagian luar rumah Melayu pesisir.

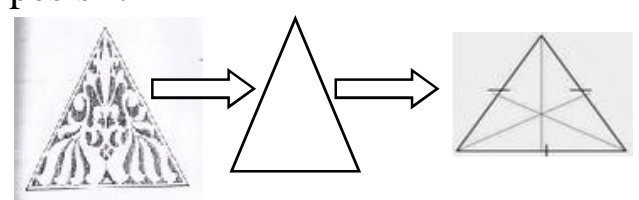

\section{Simetri Lipat Segi Tiga}

9. Ragam hias Roda Sula

$$
\text { Ragam hias ini }
$$

menggambarkan roda dengan tujug mata sula sebagai jari0jari rodanya. Mata sula melambangkan kekuatan dan ketahanan, sefangkan 7 melambangkan tujuh petala langit. Ornamen ini terdapat pada lobang bawah rumah.

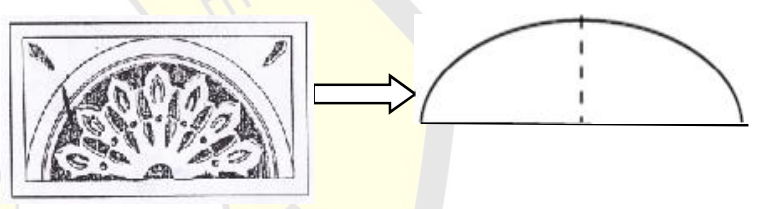

\section{Simetri Lipat Busur Lingkaran}

Ragam Hias Melayu menurut T.H.M Lah Husny secara jelas menggambarkan ragam hias Melayu, dapat dilihat di bawah ini:

1. Bulan-bulan

2. Pucuk Rebung

3. Pucuk Rebung Berbanjar

Dalam karya lain, Tennas Effendi dan Emmy Kadir (2003: 147) mengemukakan ragam hias untuk tempat gantungan lampu di loteng, yang disebut kaluk pakis bulan penuh, yang gambarnya adalah sebagai berikut:

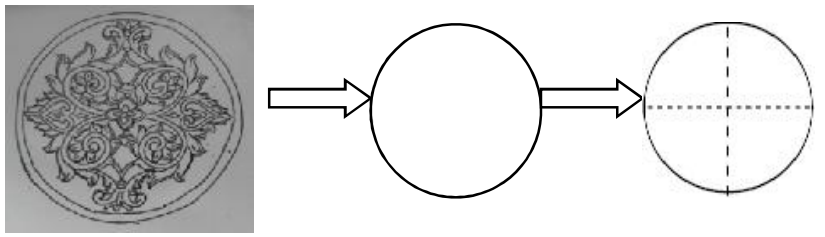

Simetri Lipat Lingkaran 
selain itu juga Tennas Effendi dan Emmy Kadir (2003: 131) menggunakan ragam hias untuk Lubang angin yang disebut Lubang angin Berwajik-wajik yang gambarnya sebagi berikut
Barton, B. (1996). Making Sense of Ethnomathematics: Ethnomathematics is Making Sense. Educational Studies in Mathematics, 31(1-2), 201-33. Rosa \& Orey, 2006).

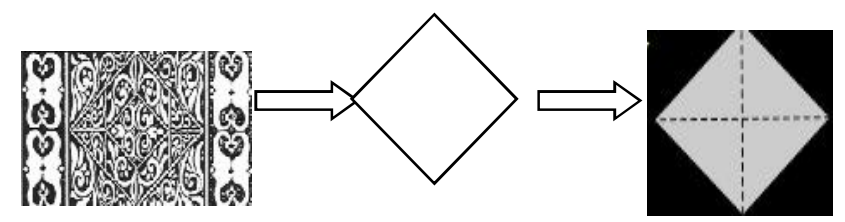

Simetri Lipat Belah Ketupat

Simpulan dan Saran

\section{Simpulan}

Dalam Ragam Hias Melayu Banyak hal yang dapat di pelajari dimana berhubungan dengan matematika salah satunya ialah keterkaitan Ukiran Melayu yang berhubungan dengan materi simetri Lipat yang di pelajari di tingkatan sekolah dasar. Sehingga dengan keterkaitan tersebut membuat siswa dapat mengetahui bahwa hubungan budaya dan matematika merupakan salah satu kesatuan yang saling berkaitan.

\section{Saran}

Semoga Jurnal Ini dapat bermanfaat dan peneliti selanjutnya dapat menemukan simetri lipat untuk bangun datar yang lain seperti Layang-layang.

\section{Daftar Pustaka}

Astri Wahyuni, dkk. 2013. Peran Etnomatematika dalam Membangun Karakter Bangsa. Prosiding dalam Seminar Nasional Matematika dan Pendidikan Matematika FMIPA UNY: Yogyakarta.
Farizal Nasution. 2007. Budaya Melayu. Yogyakarta: Adicita Grup dan Balai Kajian dan Pengembangan Budaya Melayu.

Rosa, M. \& Orey, D. C. 2011. Ethnomathematics: the cultural aspects of mathematics. Revista Latinoamericana de

Etnomatemática, 4(2). 32-54.

Taufik Ikram Jamil, dkk. 2012. Ragam Budaya Melayu Riau. Lembaga Adat Melayu Riau: Pekanbaru.

Tennas Effendi dan Emmy Kadir. 2003. Ragam Hias Pada Rumah Melayu Riau. Caltex Pacific Indonesia: Pekanbaru.

Zulkifli M. Nuh dan Dardiri. 2016. Etnomatematika dalam Sistem Pembilangan Pada Masyarakat Melayu Riau. Jurnal Penelitian Sosial dan Keagamaan. No 2. Hlm. 226. 